\title{
Analysis of Age and Education Effect on Employee Productivity in Sukabumi SMEs District
}

\author{
Kokom Komariah $^{1}$, Resa Nurmala ${ }^{2}$, R. Deni Muhammad Danial ${ }^{3}$ \\ \{ko2mpuspa@yahoo.com ${ }^{1}$, resanurmala@gmail.com ${ }^{2}$, rdmdanial@gmail.com ${ }^{3}$ \} \\ Universitas Muhammadiyah Sukabumi, Indonesia ${ }^{1,2,3}$
}

\begin{abstract}
Sukabumi District is located in West Java. Sukabumi District is the secondlargest regency in Java after the Banyuwangi regency. Geographically, the Sukabumi district has a lot of potentials that can be developed and can be used as a source of livelihood of the population. From its human resources, the Sukabumi district has about 2.5 million inhabitants. These three points can be used as a potential for natural resources, human resources, and a strategic geographic location. One of the factors to realize the goals of economic development is the many SMEs that can be developed in the area. The role of SMEs that is so great in supporting economic resilience must be balanced with qualified workforce productivity, so it is expected to improve SME's performance. Employee work productivity is the ability of workers to produce activities in fulfilling a company's objectives. To increase productivity, SMEs should pay attention to the age and education of workers, because the age of workers and education will affect the productivity of employees ' work, but most of the SMEs in Sukabumi district is less These two aspects. Therefore, researchers are interested to research the impact of age and education influence on the productivity of employees working in the SMEs Sukabumi Regency.
\end{abstract}

Keywords: Age, Education, Work Productivity of Employees, SMEs.

\section{Introduction}

Sukabumi District has a lot of potentials to be developed for the economic development of the region. Based on Wikipedia [1], from the geographical side, the Sukabumi district has an area of $4,128 \mathrm{~km}^{2}$. Sukabumi District boundary is $40 \%$ bordered by oceans and $60 \%$ island. Other than that, human resources of Sukabumi Regency. The population in the year 2017 reached 2,523,992 inhabitants and a population spread of 609 people $/ \mathrm{km}^{2}$. Judging from the natural resources, human resources and the geographical location of the Sukabumi District has a great potential to do the economic development of the region.

Development planned or that will be done by the local government should be able to support the development of the central government in order to optimize the economic increase of the country. One of the efforts made to improve the economic development in an area is the presence of many SMEs in the area.

Table 1. Total SMEs District of Sukabumi 2018

\begin{tabular}{|c|c|c|}
\hline No & Sector & Total \\
\hline 1 & Industrial and Crafts & 1200 \\
\hline
\end{tabular}




\begin{tabular}{|c|l|c|}
\hline 2 & Farm & 766 \\
\hline 3 & Service & 58 \\
\hline 4 & Trade & 95 \\
\hline \multicolumn{2}{|c|}{ Total } & 2119 \\
\hline
\end{tabular}

Note: Number of SMEs (small and medium Enterprises) Sukabumi District 2018 (DPK SMEs).

Based on the above data, SMEs in Sukabumi District is divided into 4 sectors namely, industrial sector and handicraft, agriculture, services, and trade. But the highest SME sector is most in the industrial and handicraft sectors. SMEs are instrumental in overcoming and reducing the level of unemployment in Indonesia, and it can contribute greatly to the local income and revenue of the country. Through SMEs, the potential of natural resources and human resources in the area can be raised. But human resources limitation is also one of the serious obstacles for SMEs, therefore it is required that human resources have high working productivity.

To get employees with high productivity, one of them in the selection of employees should consider age and education. Employee working age is expected to affect someone's productivity at work. The Labor age of one will also affect the success of doing both physical and nonphysical work. In general, old-age manpower has a weak and limited physical power, otherwise, a young workforce has strong physical abilities [2].

Need for qualified human resources is able to increase the productivity of each workforce. With increasing labor productivity, more products will be produced and can increase the industry income that will realize the progress of the industry. Thus, the level of education is required for every person because education will improve their personality quality. The level of education that a person has affects their mindset, attitudes, and behaviors and is believed to be higher-educated employees, as well as their productivity levels.

\section{Methods}

This research uses descriptive and associative research. The location used in this research is SME's regency of Sukabumi. The analysis technique used is multiple linear regression to gain its significance. The technical collection of data used in this study is observation, interview, and documentation.

The data analysis method used in this research is to disseminate questionnaires to respondents, process data and analyze them, and conclude the results of analysis whether age and education will affect the productivity of employees working in SMEs in the Sukabumi District. The population in this research is an employee who works for SMEs in the Sukabumi district. The sampling technique used is a sampling cluster because the objects are researched enough scope and the response amount is quite a lot so that the sampling using stratified random sampling, as for the number of respondents filling Questionnaire of 100 employees divided from all SMEs.

Analysis of data used multiple regression linear regression and performed with the help of the SPSS application program. Based on the regression model can be done some test-T. The test is to know whether or not the partial influence (own) is given a free variable (X) individually to the bound variable $(\mathrm{Y})$. 


\section{Results and Discussion}

There are two groups of requirements for high individual productivity including the first group which is the level of education and expertise, the type of technology and the production, working conditions and health, physical and mental abilities. Furthermore, the second group is mental attitude (to the task), associates and supervisors, diversity of tasks, incentive system (System of wages and bonuses) and job satisfaction according to Sinungan [3].

According to Simanjuntak [4], The factors affecting the work productivity of the company's employees can be classified in two groups, namely the one that concerns the quality and physical capabilities of employees which include: level of education, exercise, motivation Work, work ethic, mental and physical capabilities of employees. Second, supporting facilities, which include the working environment, including production, facilities and production equipment, safety level, and working welfare. Then the welfare of its employees covering management and industrial relations.

\subsection{Age of Respondents}

Younger workers do not have as much work experience as those of the older workforce. One of the factors that have an influence on employee productivity is the age factor according to Amron in Mahendra [5]. The age that is still in the productive period usually has a higher level of productivity than the workforce that is old so that the physical has become weak and limited.

The results showed that of the 100 respondents, the age range working in SMEs in Sukabumi Regency ranged from:

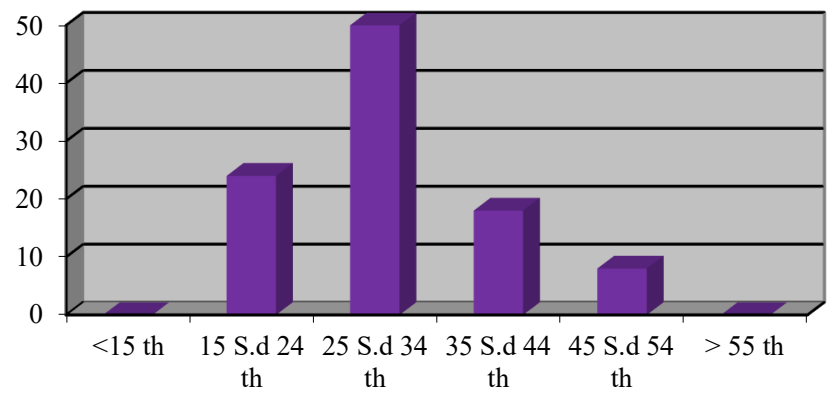

Fig. 1. Age of Respondent

Source: Research Result, 2018.

From the resulting data explained that the range of age from 25 to 34th that many work in SMEs scattered in Sukabumi district, then the age of $15 \mathrm{~S}$. D 24th in the second position as much as 24 respondents, all three ages $35 \mathrm{~S}$. D 44th as many as 18 respondents and the last age 45 S. D 54th as many as 8 respondents. If judging from the LAW No. 13 of 2003 [13] Chapter 1 of article 1 paragraph 2, it is written that the workforce is anyone who can do the work to produce goods or services both to meet their own needs and for the community. In Indonesia, there is an age limit to work, ranging from 15 years to 64 years. BPS distinguishes its productive age into 2 categories, the first very productive age (15-49), and both productive age (50-64). 
The productive age saw from the age category also greatly affects the working productivity, because one of them at the age of 25 to 34th from the psychological side has matured not too young and physically still strong because it is not old age. The central statistic [6] that the productive age is the characteristic of having work, active, energetic in work, hard work, smart work, being self-reliant, not ignoring spirituality and religiosity, having a living view and future insight.

\subsection{Level of Education of Respondents}

According to Suwatno and Priansa [7] education is related to the enhancement of general knowledge and understanding of our environment thoroughly. Therefore, education is a continuous process that cannot be separated from the organizational system to improve the productivity of work. The existence of new officers and who will occupy a new position, encouraging the person to always conduct education and training programs.

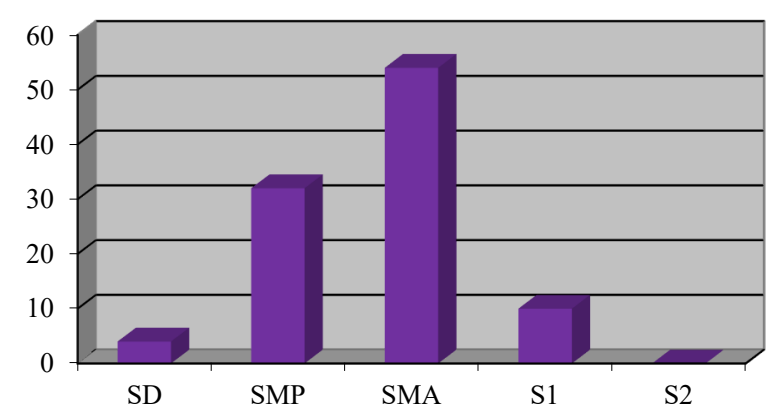

Fig. 2. The educational level of the respondent

Source: Research Result, 2018.

The highest level of education of respondents is high school education $54 \%$ or 54 people, both junior high school $32 \%$ of people, third Strata 1 as much as $10 \%$ or 10 people, elementary school as much as $4 \%$ or 4 people and Strata 2 does not exist. This means that employees who work in SMEs in the Sukabumi district are still many from high school and junior high school graduates compared to strata 1 and strata 2. At least SMEs in Sukabumi district has been seeking to take its employees according to government regulation in compulsory education program 12 years. This means that high school graduates are well-qualified for their employee productivity. Graduates S1 only a little because they prefer to work in companies that already have a name or a big company than in SMEs. Also, the salary factor can also affect the owner of the SME if they appoint employees from S1 or S2 graduates. Graduates of S1 and S2 have followed the regional minimum wage salary.

\subsection{Education with Workforce Productivity}

The higher the level of one's education, the higher the level of productivity or labor performance according to Simanjuntak [8]. Generally, people who have a higher formal or informal education will have a wider insight. The high awareness of the importance of productivity will encourage the manpower involved in performing productive actions. 
Table 2. Coefficients

\begin{tabular}{|c|l|r|r|r|r|r|}
\hline \multicolumn{2}{|c|}{ Model } & \multicolumn{2}{|c|}{$\begin{array}{c}\text { Unstandardized } \\
\text { Coefficients }\end{array}$} & $\begin{array}{c}\text { Standardized } \\
\text { Coefficients }\end{array}$ & \multirow{2}{*}{$\mathrm{t}$} & \multirow{2}{*}{ Sig. } \\
\cline { 3 - 8 } \multicolumn{2}{|c|}{} & B & Std. Error & Beta & & \\
\hline \multirow{2}{*}{1} & (Constant) & 14,204 & 3,996 & & 3,554 & 0,001 \\
\cline { 2 - 8 } & X2(Pendidikan) & 1,649 & 0,087 & 0,887 & 19,057 & 0,000 \\
\hline
\end{tabular}

Based on the SPSS "coefficients" output table above the known significance (SIG) value of education variables (X2) is 0.000 . Because of the value of sig $0.000<0.05$, it can be concluded that $\mathrm{H} 1$ or hypothesis is received, meaning there is influence on productivity of work.

Table 3. Model Summary

\begin{tabular}{|c|c|c|c|c|c|c|c|c|c|}
\hline \multicolumn{10}{|c|}{ Model Summary } \\
\hline \multirow[b]{2}{*}{ Model } & \multirow[b]{2}{*}{$\mathrm{R}$} & \multirow[b]{2}{*}{$\begin{array}{c}\mathrm{R} \\
\text { Square }\end{array}$} & \multirow[b]{2}{*}{$\begin{array}{l}\text { Adjusted } \\
\text { R Square }\end{array}$} & \multirow{2}{*}{$\begin{array}{l}\text { Std. Error } \\
\text { of the } \\
\text { Estimate }\end{array}$} & \multicolumn{5}{|c|}{ Change Statistics } \\
\hline & & & & & $\begin{array}{c}\text { R Square } \\
\text { Change }\end{array}$ & $\begin{array}{c}F \\
\text { Change }\end{array}$ & df1 & df2 & $\begin{array}{c}\text { Sig. F } \\
\text { Change }\end{array}$ \\
\hline 1 & $.887^{\mathrm{a}}$ & 0,788 & 0,785 & 3,11792 & 0,788 & 363,178 & 1 & 98 & 0,000 \\
\hline
\end{tabular}

Based on the output above known as R Square value of 0.078 , this value stated that the effect of variable X2 (education) on variable $\mathrm{Y}$ (work productivity) is $7.8 \%$ and the remaining 92.2 is influenced by other factors outside the variable Research. One of them is because the education that has been taken by many employees who have been per the government program must study 12 years.

The cause of employee difficulties in achieving work productivity is much due to factors outside of this study. This research can also be continued to find other factors. According to Panji and Anoraga [9], factors influencing work productivity, such as education, job motivation, work discipline, skills, attitudes, and work ethics, nutrition and health, income levels, work environment and Working climate, technology, production facilities, social security, management, and achievement opportunities.

\section{Conclusion and Suggestion}

\subsection{Conclusion}

a) Based on the results of the study of the age of workers in the SME district of Sukabumi can be concluded that the worker in the SME district of Sukabumi belongs to the productive age of 15-64th, besides the highest in the age range of 25 sd 34 th $50 \%$.

b) Seen from the education of workers in SMEs district of Sukabumi already have a realization of the importance of education, at least the workers in the majority of $54 \%$ already pay attention to education 12 years, according to which is in the Require by Government.

c) Based on the table Output SPSS "Coefficient" his show that the result of the hypothesis was received, there is an educational influence on the productivity of employees work in the SME district Sukabumi.

d) Views from the value of R. Square only $7.8 \%$, meaning many other variables can affect the productivity of work. 


\subsection{Suggestion}

a) SMEs in Sukabumi District must maintain the quality of human resources seen from various factors that affect the productivity of its work of one age and education, to realize the innovation and creativity of products/services produced by its employees, because with human resources that have high productivity, it will increase the sales turnover of the SME owners.

b) The owners of SMEs in Sukabumi district should also pay attention to other factors of employee work productivity as well as: the motivation of work, discipline, skills, attitudes, and ethics of work, nutrition and health, income level, work environment and working climate, technology, production facilities, social security, management, and opportunity achievement.

c) The government should seek better equality of education compulsory study 12 years for the people of Sukabumi district.

\section{References}

[1] Wikipedia, "Kabupaten Sukabumi," Wikipedia. [Online]. Available: https://id.wikipedia.org/.

[2] T. I. Amron, "Analisis Faktor-Faktor yang Berpengaruh Terhadap Produktivitas Tenaga Kerja pada Outlet Telekomunikasi Seluler Kota Makasar," J. Sekol. Tinggi Ilmu Ekon. Nobel Indones., 2009.

[3] M. Sinungan, Produktivitas apa dan Bagaimana. Bumi Aksara, 2018.

[4] P. Simanjuntak, "Manajemen dan Evaluasi Kerja," Jakarta FEUI, 2005.

[5] A. D. Mahendra and N. Woyanti, "Analisis pengaruh pendidikan, upah, jenis kelamin, usia dan pengalaman kerja terhadap produktivitas tenaga kerja (Studi di Industri Kecil Tempe di Kota Semarang).” Fakultas Ekonomika dan Bisnis, 2014.

[6] Badan Pusat Statistik, "Kelompok Usia Produktif," Badan Pusat Statistik, 2016. .

[7] H. Suwatno and D. J. Priansa, "Manajemen SDM dalam organisasi Publik dan Bisnis," Bandung Alf., 2011.

[8] P. Simanjuntak, "Pengantar Ekonomi Sumber Daya Manusia," Jakarta FEUI, 1998.

[9] P. Anoraga, "Psikologi Kerja, PT," Rineka Cipta, Jakarta, 2009. 